\title{
APLIKASI REPOSITORY PADA PERPUSTAKAAN UNIVERSITAS BANTEN JAYA
}

\author{
Irma Yunita Ruhiawati', Waliadi Gunawan ${ }^{2}$, Neshya Faniya ${ }^{3}$ \\ ${ }^{1,2}$ Dosen Fakultas Ilmu Komputer Universitas Banten Jaya \\ ${ }^{3}$ Alumni Fakultas Ilmu Komputer Universitas Banten Jaya \\ Jl. Ciwaru Raya No. 73 Warung Pojok, Kota Serang - Banten \\ E-mail:irma.yunita@unbaja.ac.id ${ }^{1}$, waliadigunawan@unbaja.ac.id ${ }^{2}$,
}

\begin{abstract}
ABSTRAK
Sistem informasi repository Universitas Banten Jaya pada saat ini masih manual, proses untuk mengakses karya ilmiah dilakukan dengan cara meminjam melalui perpustakaan. Tujuan dari perancangan sistem ini untuk mempermudah mahasiswa mencari referensi karya ilmiah secara online. Pengembangan perangkat lunak menggunakan metode waterfall, pada tahap analisa dan perancangan sistem usulan penelitian mengguanakan pemodelan Diagram Arus Data (DAD). Pengumpulan data dilakukan dengan wawancara langsung dengan kepala perpustakaan dan staf Universitas Banten Jaya serta melakukan observasi di Perpustakaan Universitas Banten Jaya dari wawancara dan observasi didapatkan informasi prosedur yang sedang berjalan dan kendala yang dihadapi oleh mahasiswa, kemudian data tersebut dianalisa dan digunakan sebagai informasi untuk merancang aplikasi. Proses perancangan aplikasi dilakukan dengan menggunakan bahasa pemrograman PHP dan database MySQL. Hasil penelitian ini adalah berupa rancangan aplikasi repository yang dapat memudahkan mahasiswa dalam mengakses karya ilmiah pada Perpustakaan Universitas Banten Jaya. Dengan menggunakan aplikasi Repository dapat mengurangi terjadinya kerusakan, kehilangan koleksi karya ilmiah, mempermudah penggunaan perpustakaan dan menghemat penggunaan ruangan dan dengan diterapkan aplikasi Repository diharapkan dapat menunjang kinerja perpustakaan dan membantu para pengguna perpustakaan dalam mencari informasi yang dibutuhkan.
\end{abstract}

Kata Kunci: Perpustakaan, Repository, Waterfall.

\section{PENDAHULUAN}

Perkembangan Information and Communication Technology (ICT) yang cukup pesat turut membawa perubahan signifikan dalam berbagai bidang, termasuk perpustakaan. Pemanfaatan ICT dalam mengelola dan menjalankan oprasional perpustakaan adalah sebagai tempat penyimpanan data perpustakaan yang berupa record dan arsip, sedangkan pnerapan ICT dalam penyimpanan data perpustakaan, jurnal ilmiah, laporan kerja praktek, dan laporan skripsi itu dilakukan di tempat yang disebut repository.

Repository adalah konsep untuk mengumpulkan, mengelola dan menyebarkan seluruh karya-karya ilmiah yang dihasilkan oleh civitas perguruan 
tinggi atau sekolah tinggi (Hasan,2012:1). Beberapa perpustakaan perguruan tinggi telah menerapkan teknologi informasi dalam memenuhi kebutuhan informasi, salah satu informasi yang ada di perpustakaan adalah repository digital atau koleksi lokal. Seiring dengan perkembangan internet dan website memiliki peranan yang penting. Salah satunya perkembangan teknik penyimpanan file secara online untuk mempermudah penyimpanan dan penyebaran file tersebut.

Perpustakaan Universitas Banten Jaya saat ini hanya menerapkan sistem peminjamaan karya ilmiah secara manual, yaitu masih meminjam karya ilmiah ke perpustakaan dan masih ada biaya keterlambatan pengembalian karya ilmiah. Belum disediakan fasilitas kepada anggota perpustakaan yaitu mahasiswa, dosen pegawai Universitas Banten Jaya untuk dapat melihat laporan karya ilmiah fulltext secara online melalui website.

Permasalahan yang muncul adalah anggota kesulitan dalam melihat dan mencari laporan karya ilmiah secara fulltext dikarenakan mahasiswa harus datang ke perpustakaan terlebih dahulu untuk mencari dan membaca hardcopy karya ilmiah tersebut. Bagi mahasiswa kelas pagi, mungkin hal tersebut tidak menjadi masalah selama perpustakaan masih buka, sedangkan bagi mahasiswa kelas malam yang ratarata sudah bekerja dan hanya datang ke perpustakaan di malam hari setelah pulang kerja mengalami kesulitan terutama peminjaman karya ilmiah dapat dipinjam saat jam perpustakaan buka pukul 08.00 WIB dan harus dikembaliakan saat jam perpustakaan akan tutup pukul 21.00 WIB. Hal tersebut dirasa oleh mahasiswa kelas malam tidak maksimal dalam hal mencari karya ilmiah khususnya bagi mahasiswa tingkat akhir yang ingin mencari dan meminjam referensi karya ilmiah berupa laporan skripsi yang ada di perpustakaan. Mahasiswa kelas pagi juga merasakan permasalahan ketika jam pelayanan perpustakaan tutup atau libur, sehingga untuk mendapatkan referensi yang ada di perpustakaan Universitas Banten Jaya harus menunggu bukanya jam pelayanan perpustakaan tersebut.

Selain masalah diatas, anggota perpustakaan juga masih mengumpulkan karya ilmiah secara tradisional sehingga perlu banyak membutuhkan rak untuk tempat menyipan karya ilmiah. Dengan menggunakan aplikasi Repository anggota perpustakaan tidak perlu mengumpulkan karya ilmiah berbentuk tradisional tetapi 
harus mengumpulkan karya ilmiah berbentuk digital yang dapat di unggah oleh masing-masing anggota perpustakaan.

Dengan adanya sistem repository ini, sebuah tempat penyimpanan data yang masih manual berkembang menjadi digital yang berkaitan dengan perpustakaan dan terjadi perkembangan sistem informasi yang sangat pesat. Dengan adanya sistem ini mahasiswa Universitas Banten Jaya akan lebih mudah mengakses dan mencari referensi karya ilmiah yang sangat praktis, dan dapat diakses dimana saja dan kapan saja secara online. Selain mempermudah untuk mencari referensi karya ilmiah, penggunaan aplikasi inipun memudahkan dalam mengakses informasi karya ilmiah yang ada di perpustakaan, bahkan terhindar dari pemungutan biaya keterlambatan peminjaman buku.

\section{METODOLOGI PENELITIAN}

\section{Metode Pungumpulan Data}

Untuk mengumpulkan data dari sampel penelitian, dilakukan dengan metode tertentu sesuai dengan tujuan. Adapun metode pengumpulan data yang dipakai dalam penelitian ini yaitu:

1. Observasi, Penulis melakukan pengamatan langsung si Perpustakaan Universitas Banten Jaya, untuk mengetahui secara langsung keadaan objek penelitian yang sebenarnya. Hal ini bertujuan untuk memperoleh penjelasan mengenai data-data koleksi dan informasi yang dibutuhkan dalam penelitian. Dari hasil pengamatan yang dilakukan ditemukan bahwa perpustakaan Universitas Banten Jaya belum memiliki file digital, yaitu berupa laporan tugas akhir, laporan praktik kerja lapangan dan jurnal yang dapat di sebarkan serta menampilkan dalam jaringan internet.

2. Studi kepustakaan, yaitu teknik pengumpulan data dari berbagai buku, dokumen dan tulisan yang relevan untuk menyusun konsep penelitian serta menggunakan objek penelitian, disini penulis mencari data-data yang diperlukan dalam perancangan aplikasi Repository Perpustakaan.

3. Wawancara, yaitu teknik pengumpulan data dengan mengajukan pertanyaanpertanyaan langsung mengenai masalah-masalah yang akan dibahas pada 
lingkungan yang diteliti, disini penulis mewawancarai kepala perpustakaan dan staff perpustakaan Universitas Banten Jaya dalam melakukan proses pencarian informasi yang telah berjalan selama ini.

\section{Metode Perancangan Sistem}

Metode perancangan sistem informasi yang digunakan dalam penelitian ini yaitu metode waterfall. Metode SDLC air terjun (waterfall) sering juga disebut model sekuensial linier (sequential linear) atau alur hidup perangkat lunak secara sekuensial atau terurut dimulai analisi, desain, pengodean, pengujian dan tahap pendukung (support). Berikut adalah gambar model air terjun (waterfall):

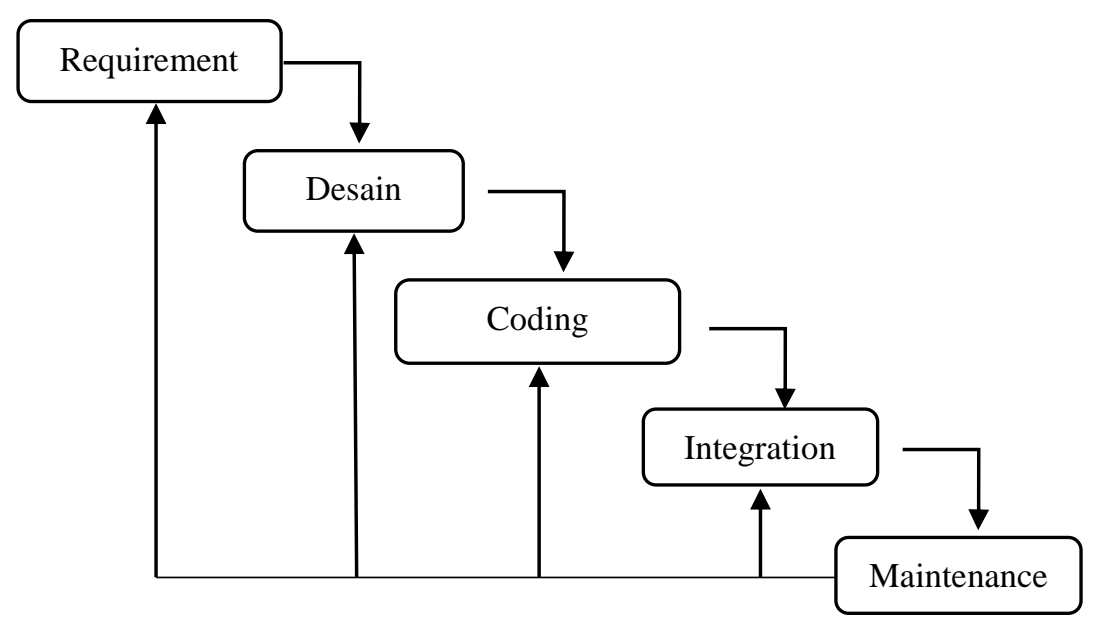

Gambar 1. Ilustrasi Model Waterfall

\section{Requirement (analisis kebutuhan)}

Dalam langakah ini merupakan analisa terhadap kebutuhan sistem. Pengumpulan data dalam tahap ini bisa melakukan sebuah penelitian, wawancara atau study literatur. Seseorang system analisis akan menggali informasi sebanyakbanyaknya dari user sehingga akan tercipta sebuah sistem komputer yang bisa melakukan tugas-tugas yang diinginkan oleh user tersebut. Tahapan ini akan menghasilkan dokumen user requirement atau bisa dikatakan sebagai data yang berhubungan dengan keinginan user dalam pembuatan sistem. Dokumen inilah yang akan menjadi acuan system analisis untuk menterjemahkan kedalam bahasa pemrograman. 
2. Design System (desain sistem)

Proses design akan menterjemahkan syarat kebutuhan kesebuah perancangan perangkat lunak yang dapat diperkirakan sebelum dibuat koding. Proses ini berfokus pada : struktur data, arsitektur perangkat lunak, representasi interface, dan detail (algoritma) prosedural. Tahapan ini akan menghasilkan dokumen yang disebut software requirement. Dokumen inilah yang akan digunakan programmer untuk melakukan aktivitas pembuatan sistemnya.

3. Coding \& Testing (penulisan sinkode program / implemention)

Coding merupakan penerjemahan design dalam bahasa yang bisa dikenali oleh komputer.Dilakukan oleh programmer yang akan meterjemahkan transaksi yang diminta oleh user. Tahapan inilah yang merupakan tahapan secara nyata dalam mengerjakan suatu sistem. Dalam artian penggunaan computer akan dimaksimalkan dalam tahapan ini. Setelah pengkodean selesai maka akan dilakukan testing terhadap sistem yang telah dibuat tadi. Tujuan testing adalah menemukan kesalahan-kesalahan terhadap system tersebut dan kemudian bisa diperbaiki.

4. Integration \& Testing (Penerapan / Pengujian Program)

Tahapan ini bisa dikatakan final dalam pembuatan sebuah sistem. Setelah melakukan analisa, design dan pengkodean maka sistem yang sudah jadikan digunakan oleh user.

5. Operation \& Maintenance (Pemeliharaan)

Perangkat lunak yang susah disampaikan kepada pelanggan pasti akan mengalami perubahan. Perubahan tersebut bisa karena mengalami kesalahan karena perangkat lunak harus menyesuaikan dengan lingkungan (periperal atau system operasi baru) baru, atau karena pelanggan membutuhkan perkembangan fungsional. 


\section{PEMBAHASAN}

Pada sistem ini struktur tampilan menu terdiri dari 2 jenis hak akses, hak akses yang pertama adalah admin dan yang ke dua adalah anggota. Struktur menu untuk kedua hak akses tersebut berbeda seperti terlihat pada gambar di bawah ini:

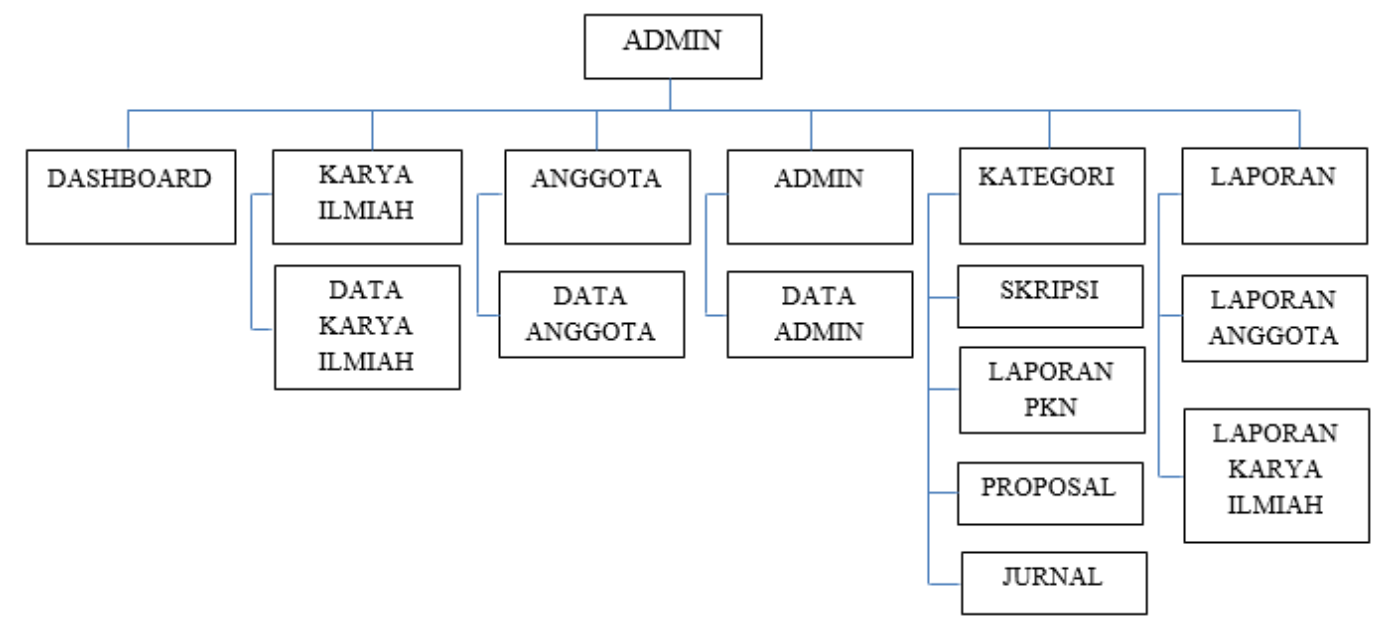

Gambar 2. Struktur Menu Admin

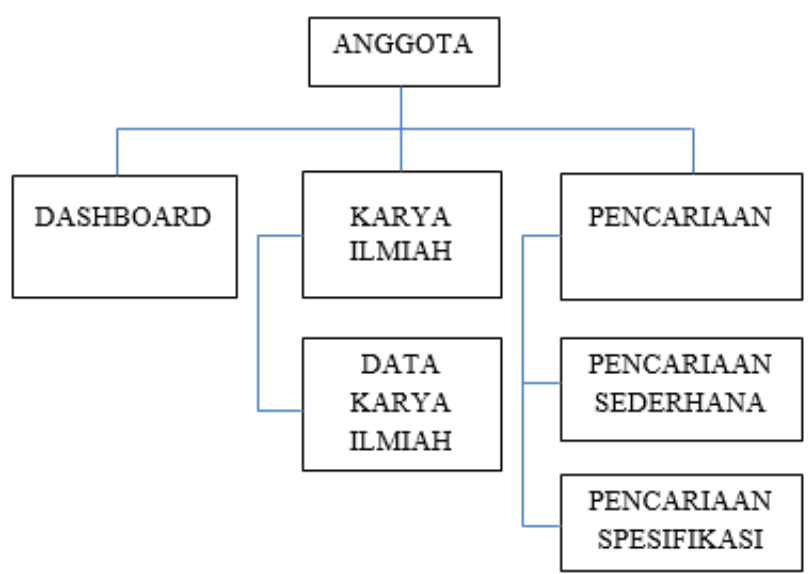

Gambar 3. Struktur Menu Anggota

\section{Implementasi Sistem}

\section{Prosedur Operasional (Manual Book)}

Dalam mengoperasikan perangkat lunak repository ini harus mengikuti prosedur-prosedur sebagai berikut :

1) Nyalakan komputer sesuai dengan standar yang telah ditentukan.

2) Pastikan aplikasi Xampp telah terinstal dan berjalan. 
3) Buka Google Crome atau Firefox, ketikan di kotak alamat web dengan mengetikan http://localhost/repository.

4) Setelah ditekan maka akan muncul sebuah halaman utama aplikasi Repository.

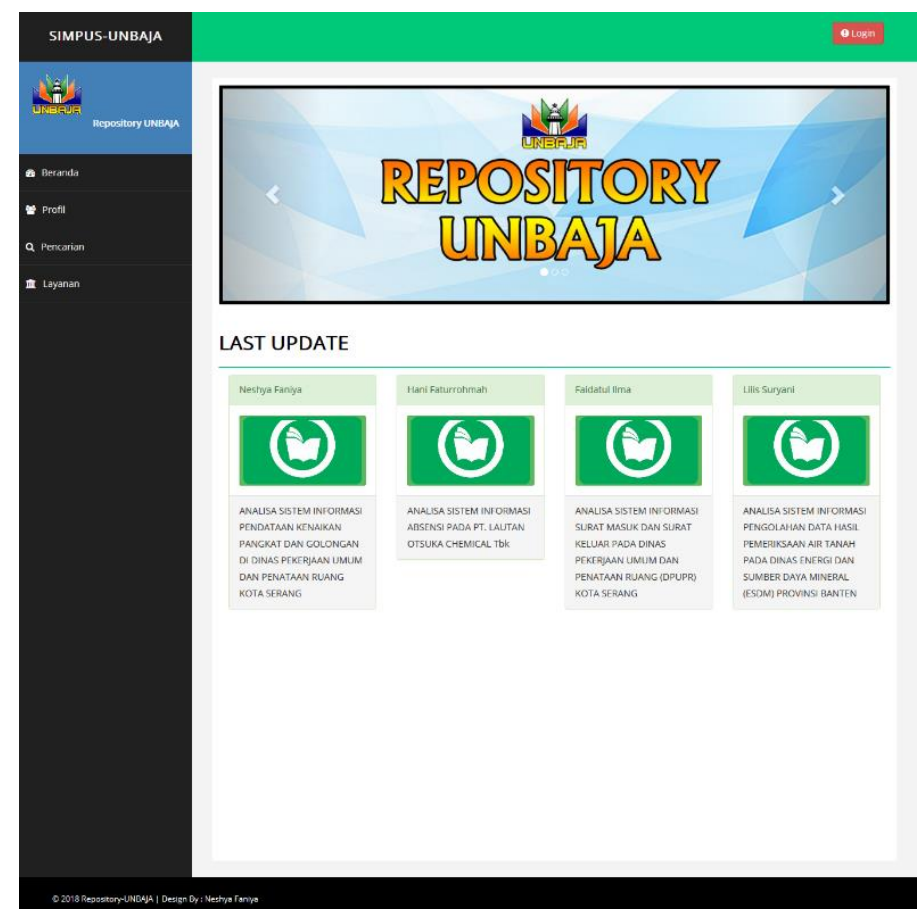

Gambar 4 Tampilan Utama Aplikasi

5) Masuk ke menu Login untuk menginputkan nama user dan kata sandi.

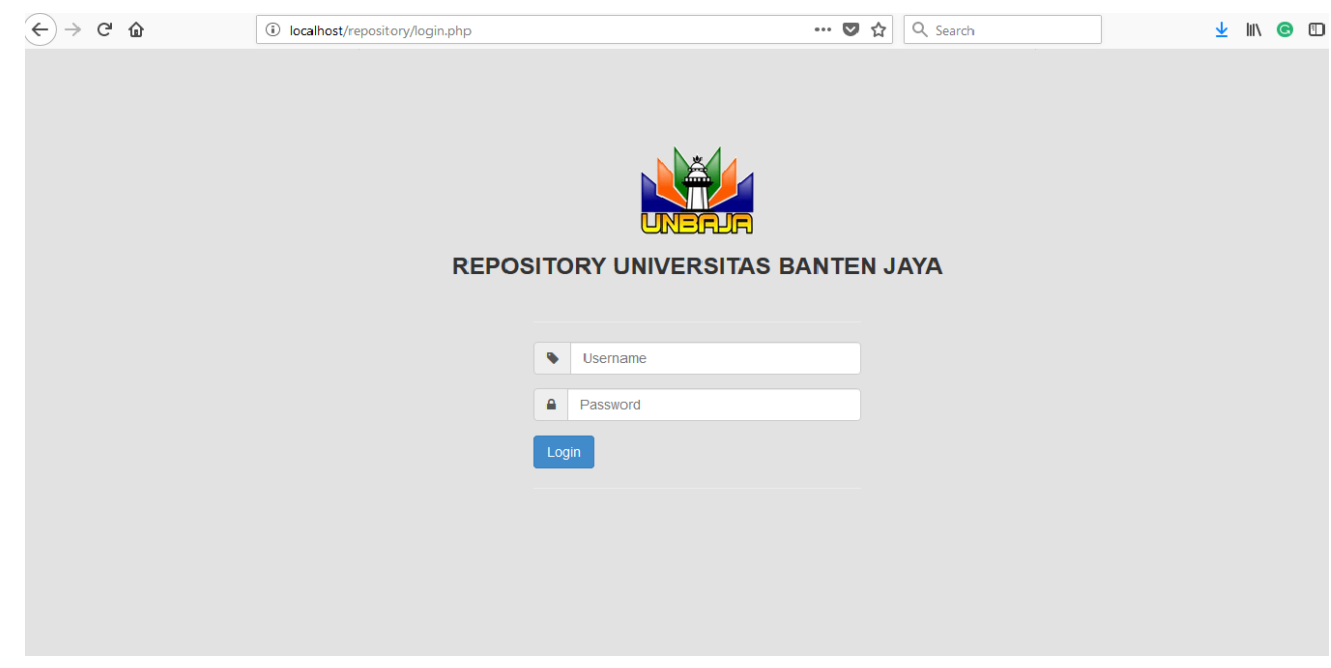

Gambar 5. Tampilan Form Login

6) Kemudian masukan nama user dan kata sandi yang sudah terdaftar pada sistem. Jika nama user dan kata sandi benar maka akan muncul menu utama untuk admin atau user. Dibawah ini contoh menu admin. 


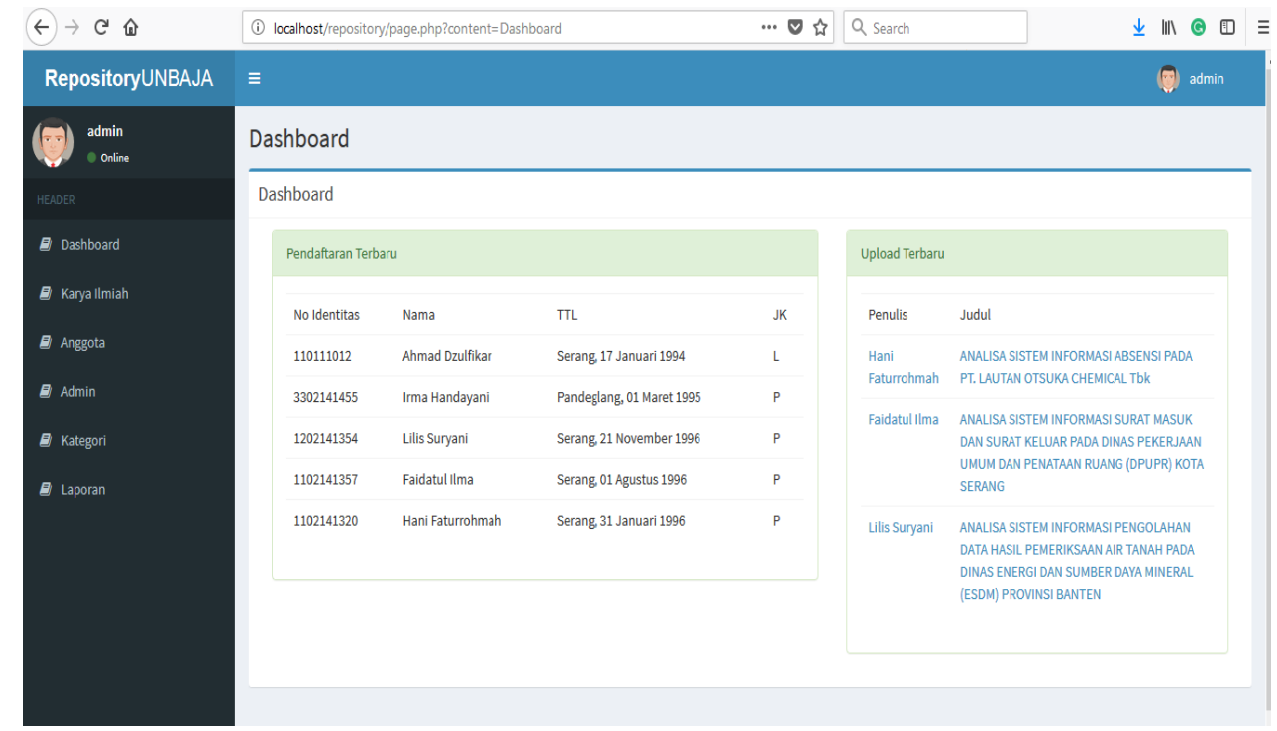

Gambar 6. Tampilan Menu Utama Admin

Menu admin terdapat beberapa bagian antara lain :

a. Tabel data Karya Ilmiah

Table karya ilmiah berisi karya ilmiah mahasiswa atau dosen pada perpustakaan.

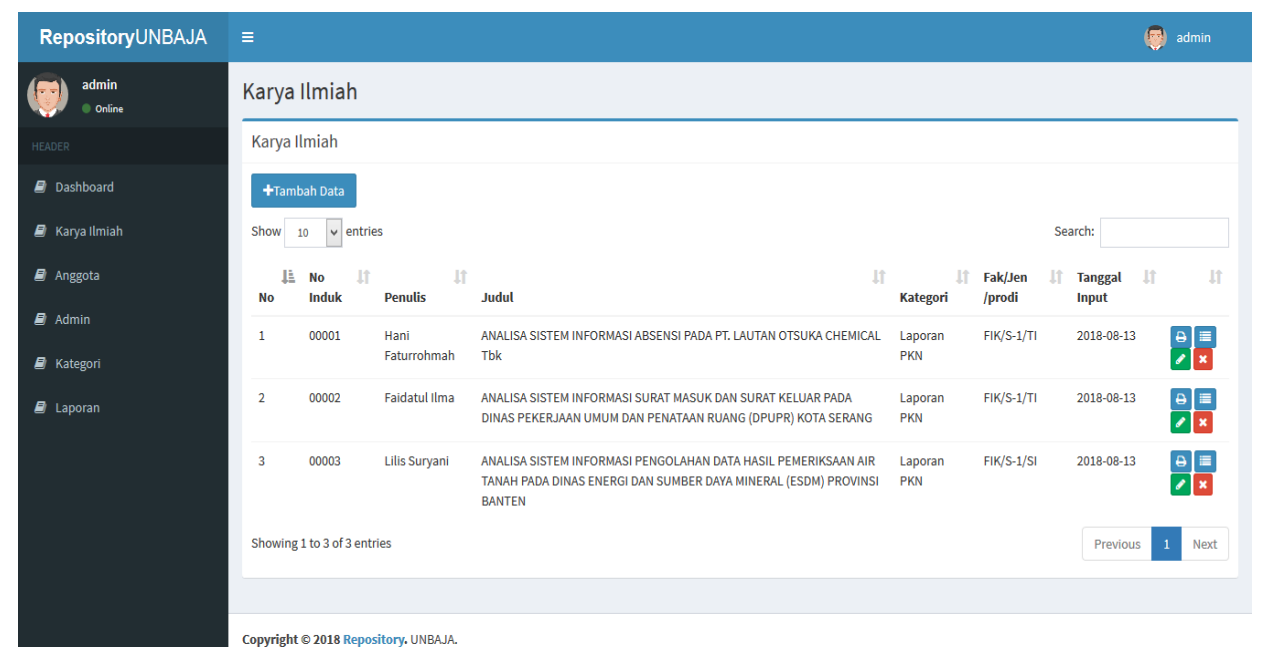

Gambar 7. Tampilan Data Karya Ilmiah

b. Tabel Anggota

Table anggota berisi data anggota perpustakaan yang sudah terdaftar pada apliaksi repository. 


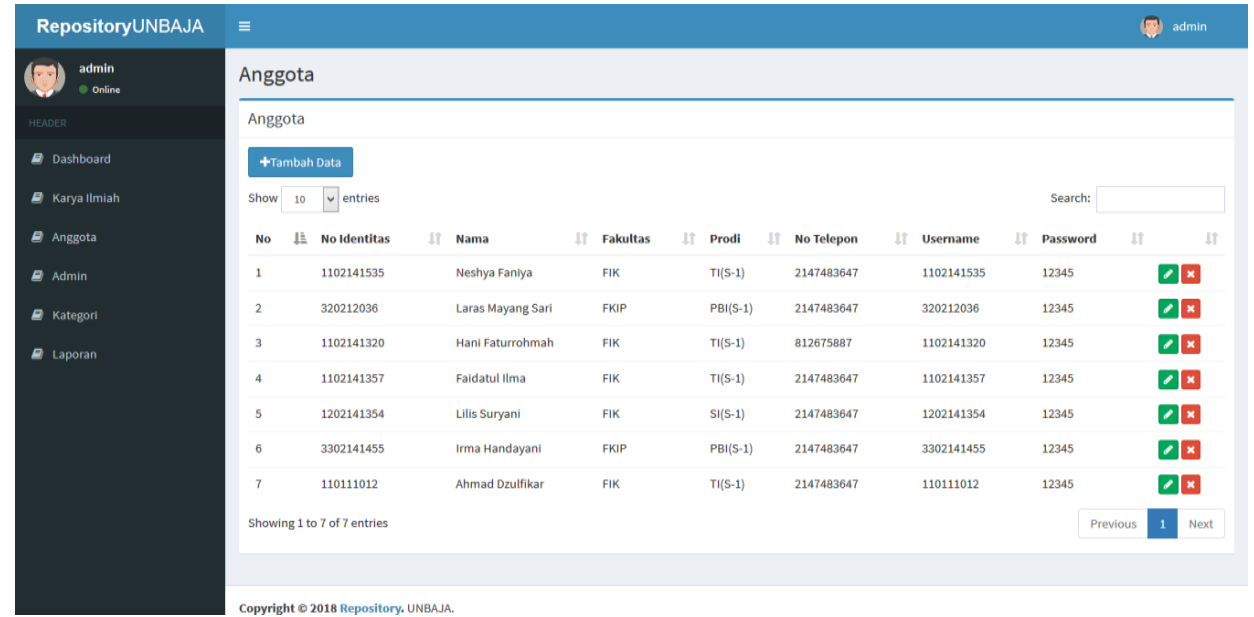

Gambar 8. Tampilan Data Anggota

c. Table Data Admin

Table admin bersi data admin perpustakaan.

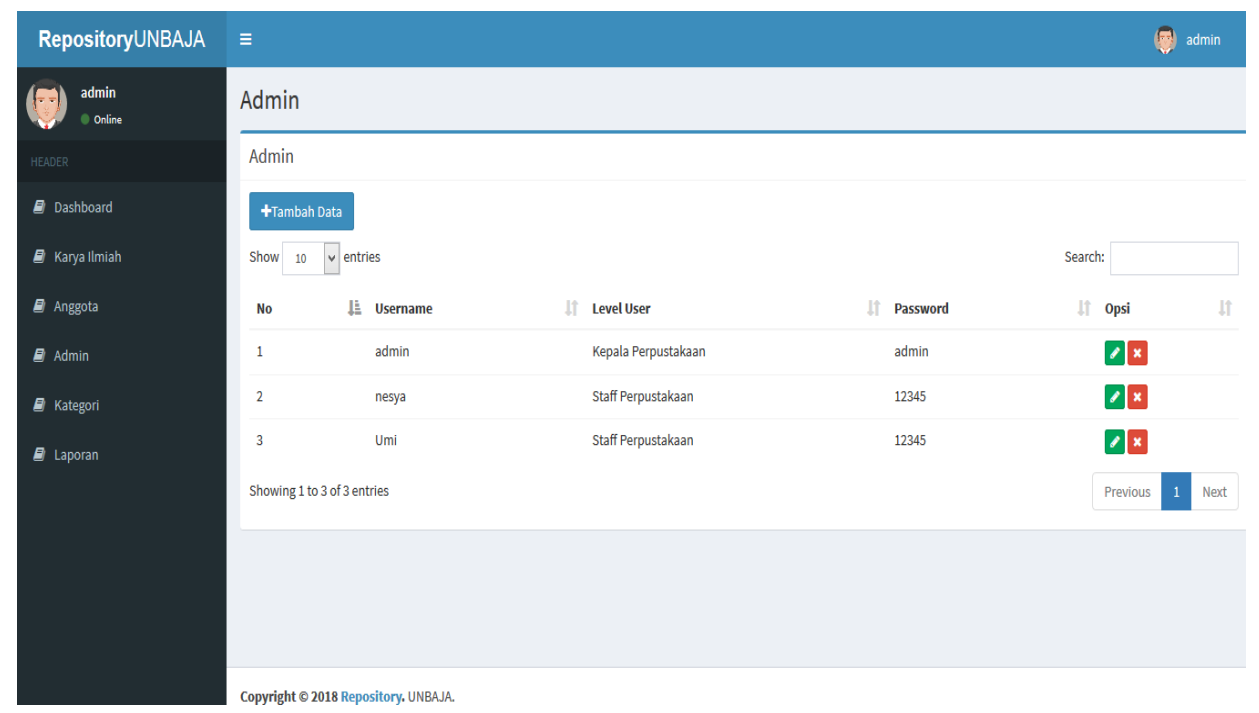

Gambar 9. Tampilan Data Admin

d. Table Data Kategori

Table kategori berisi pengelompokan jenis karya ilmiah. 


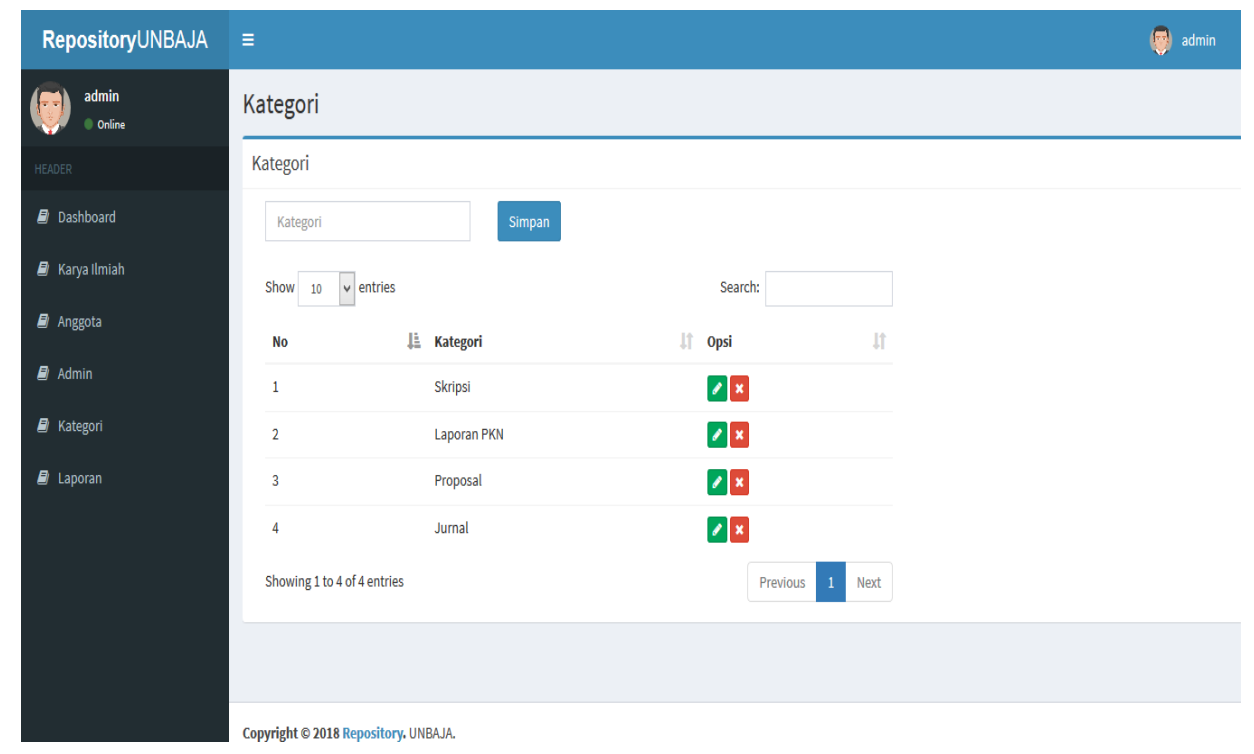

Gambar 10. Tampilan Data Kategori

e. Table Laporan

Table laporan berisi data laporan karya ilmiah dan anggota

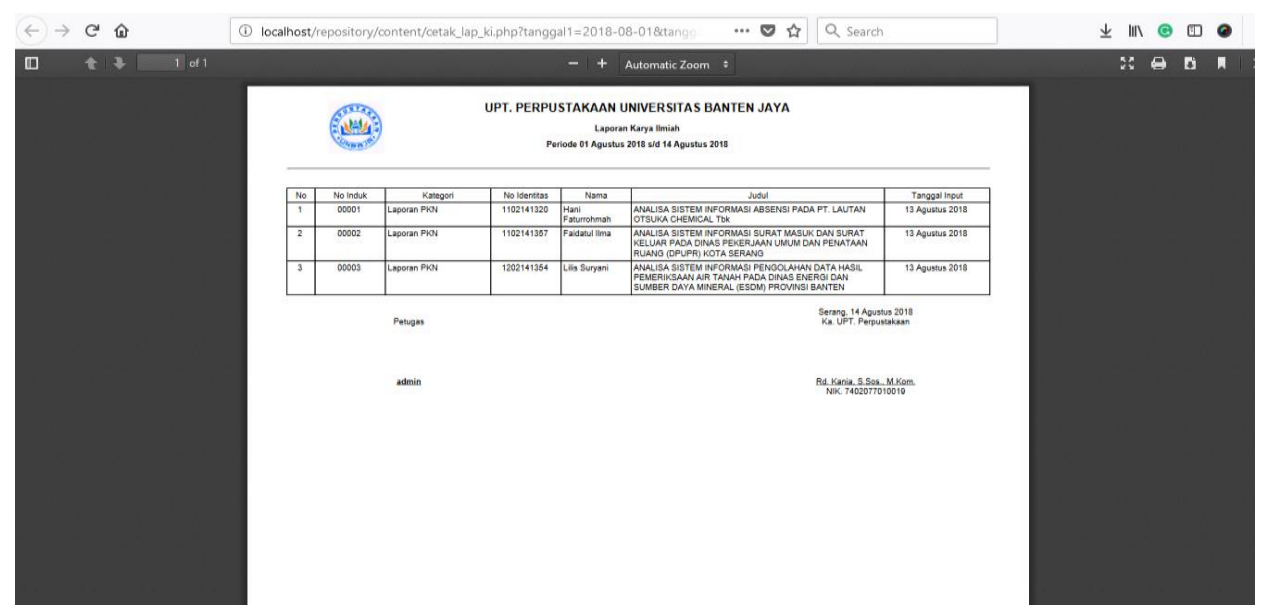

Gambar 11. Tampilan Laporan Karya Ilmiah 


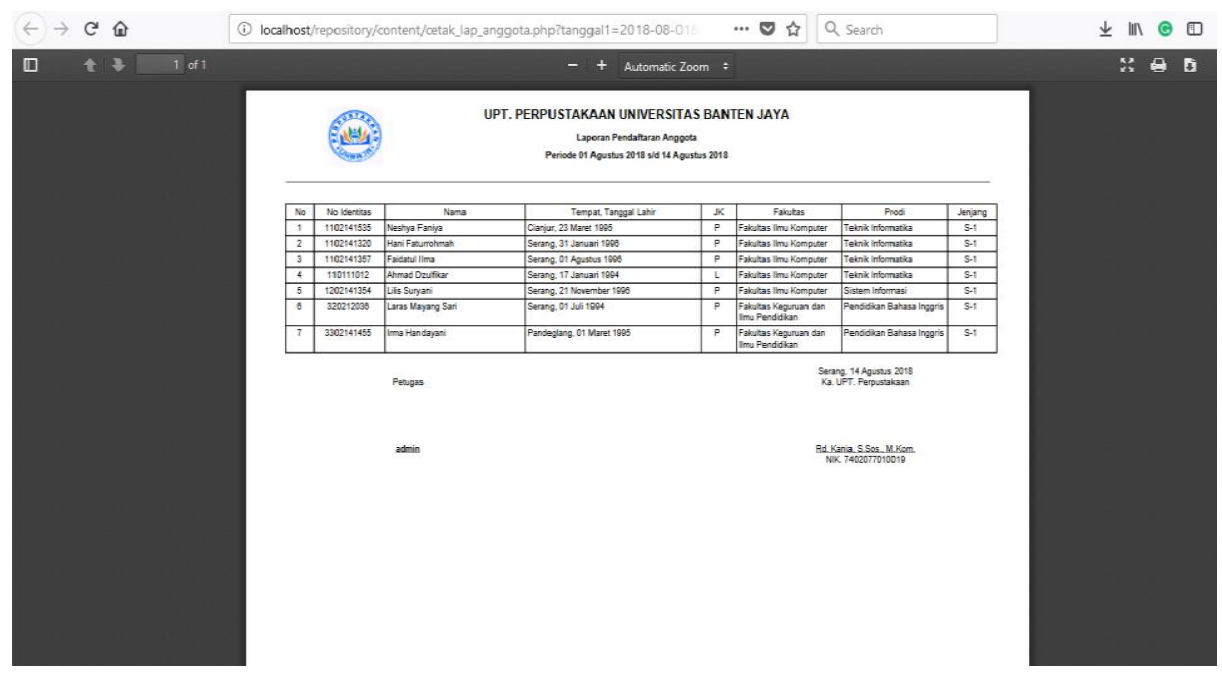

Gambar 12. Tampilan Laporan Anggota

7) Untuk menambah karya ilmiah pilih pada menu karya ilmiah dan pilih tambah data. Maka akan muncul tampilan seperti form dibawah ini dan isikan data yang ada.

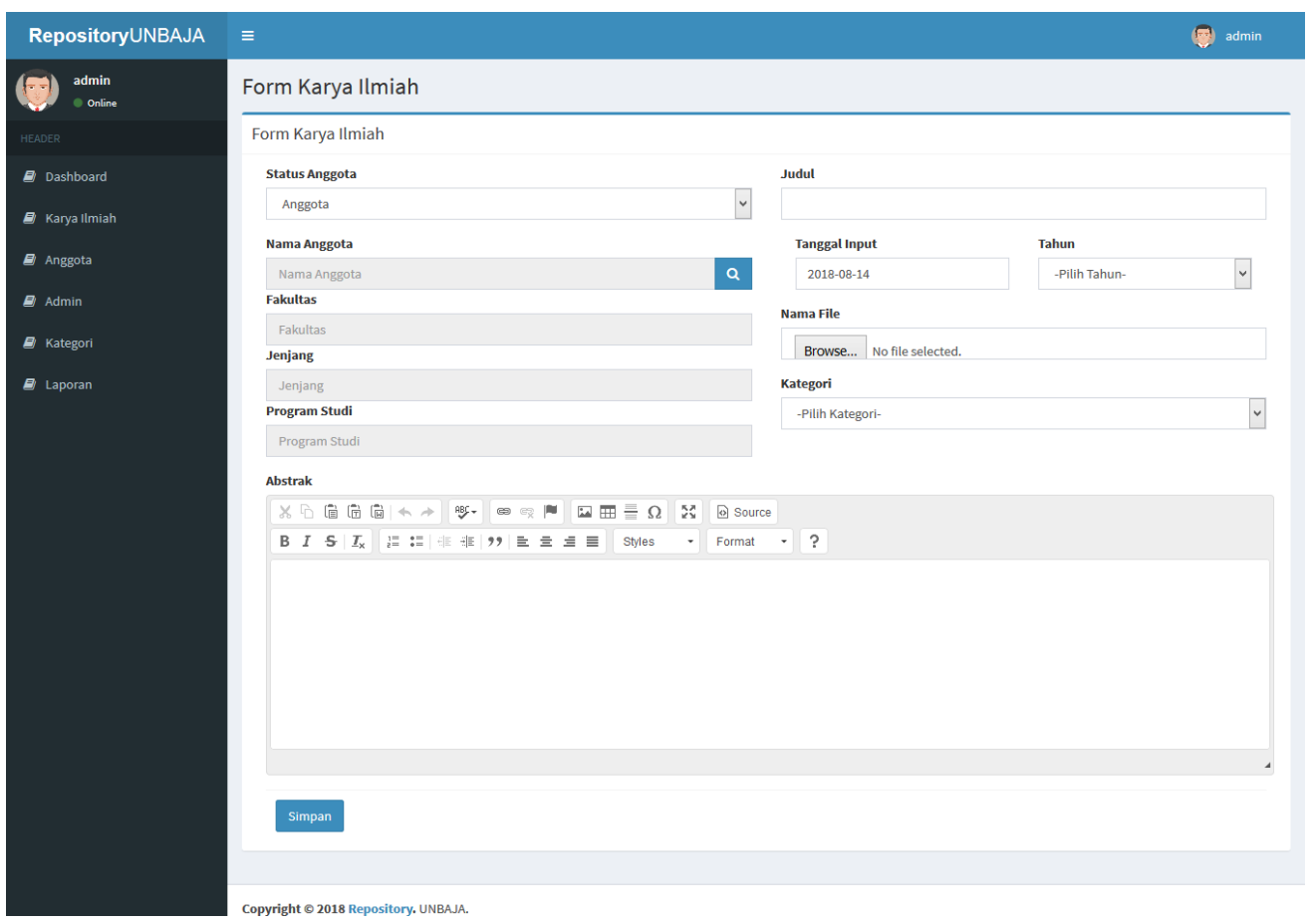

Gambar 13. Tampilan Form Input Karya Ilmiah 
8) Untuk menambahkan anggota baru pilih pada menu Anggota dan pilih tambah data. Maka akan muncul tampilan seperti form dibawah ini dan isikan sesuai data yang ada.

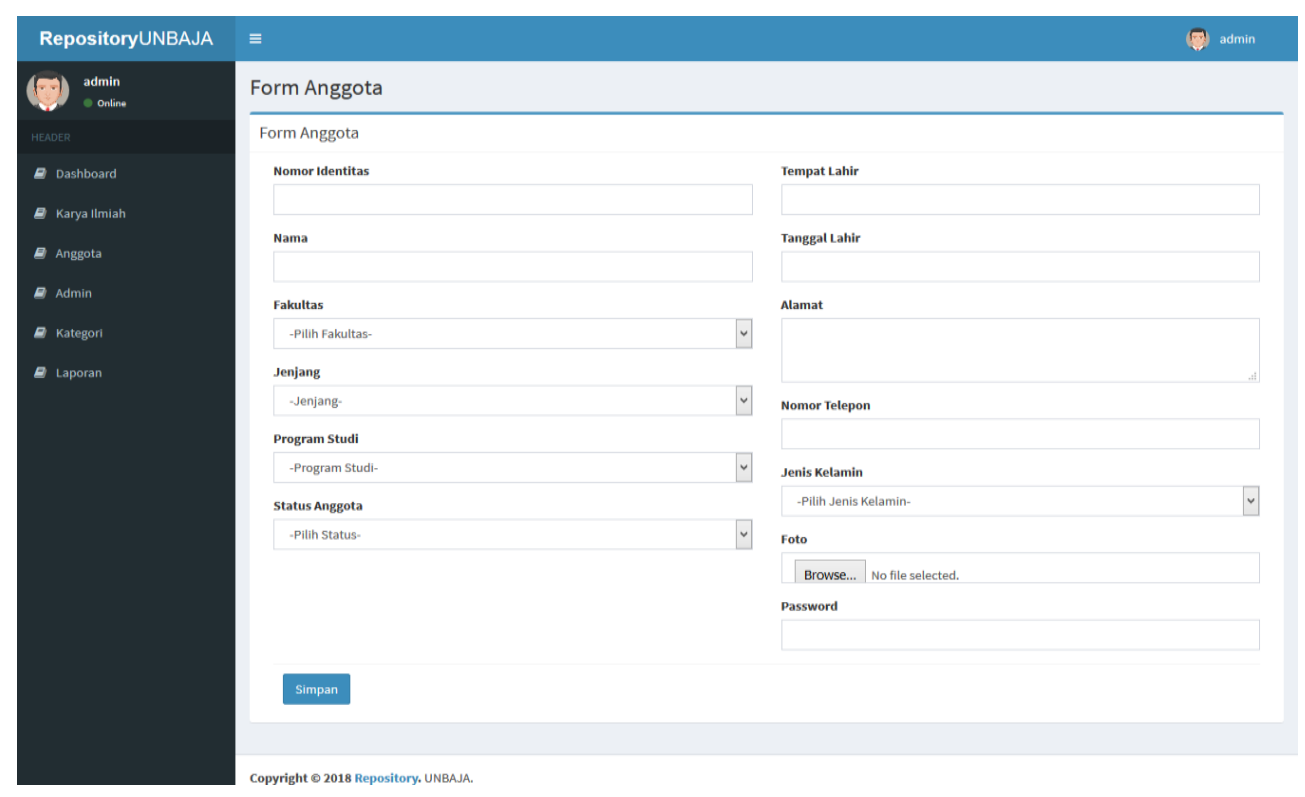

Gambar 14. Tampilan Form Input Anggota

9) Untuk menambahkan admin baru pilih pada menu Admin dan pilih tambah data. Maka akan muncul tampilan seperti form dibawah ini dan isikan sesuai data yang ada.

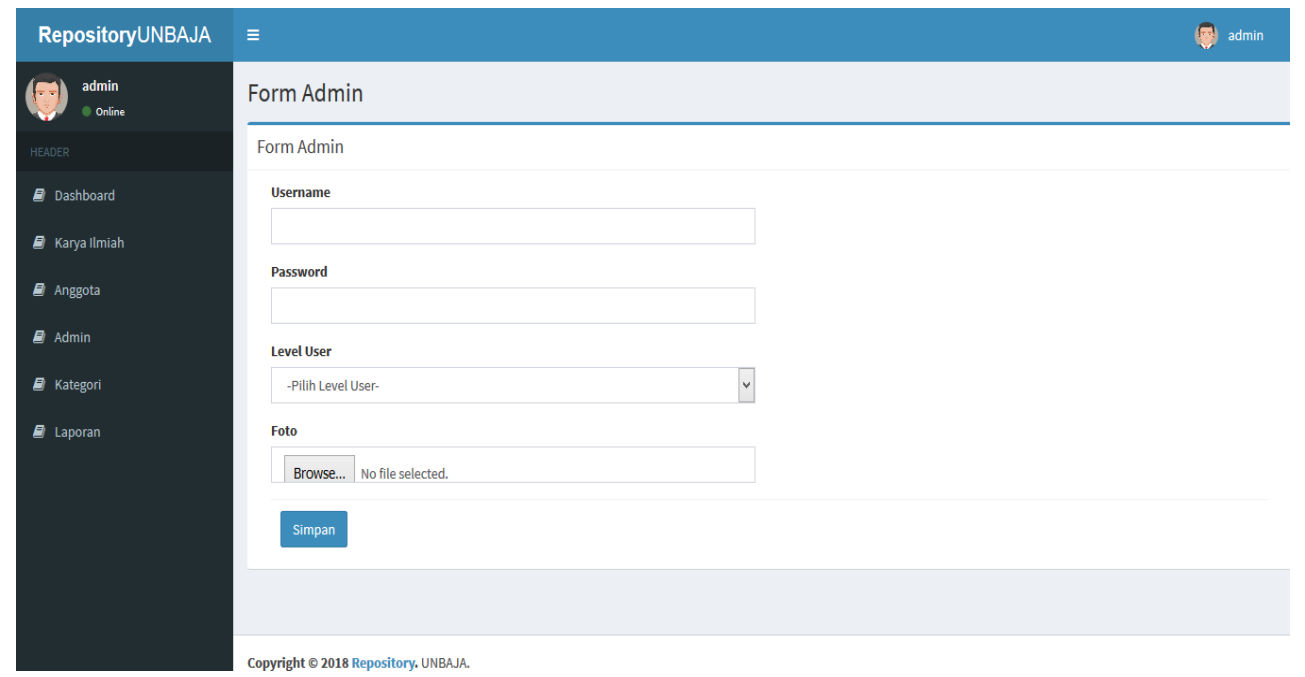

Gambar 15. Tampilan Form Input Admin 
10) Untuk menambahkan kategori baru pilih pada menu Kategori maka akan muncul seperti dibawah ini dan isikan sesuai dengan data yang ada.

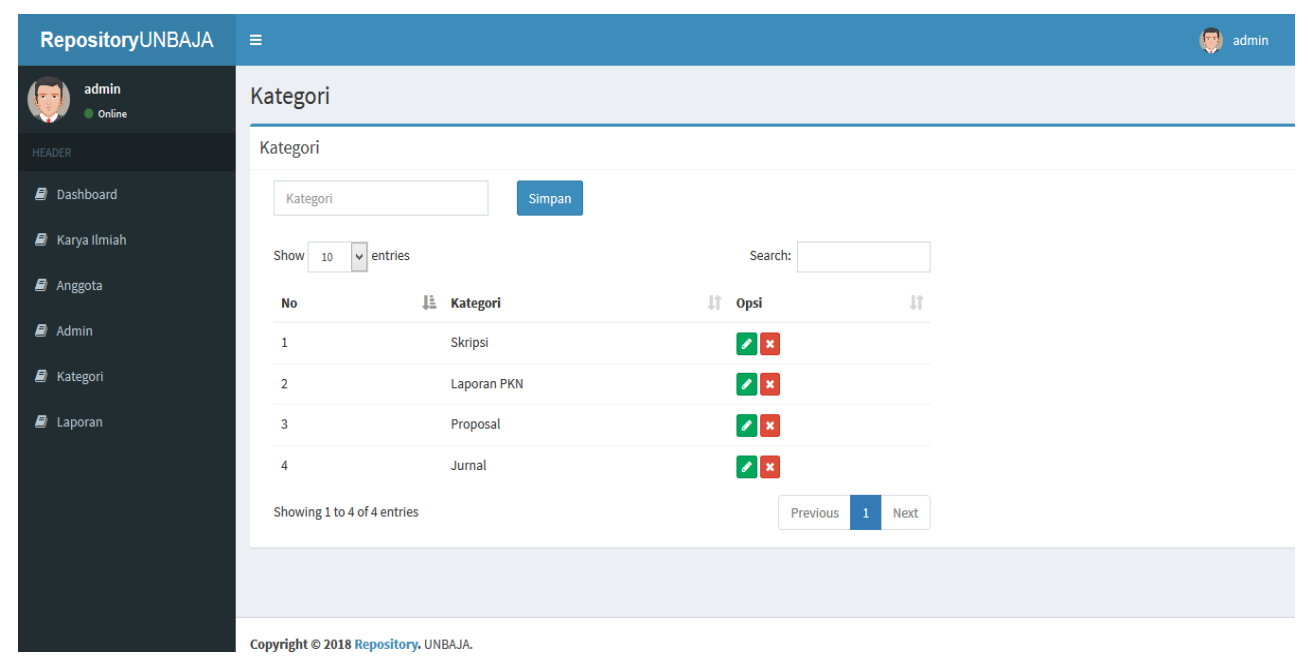

Gambar 16. Tampilan Form Kategori

11) Untuk mencetak laporan maka pilih pada menu laporan maka akan muncul seperti dibawah ini dan isikan tanggal sesuai yang di inginkan.

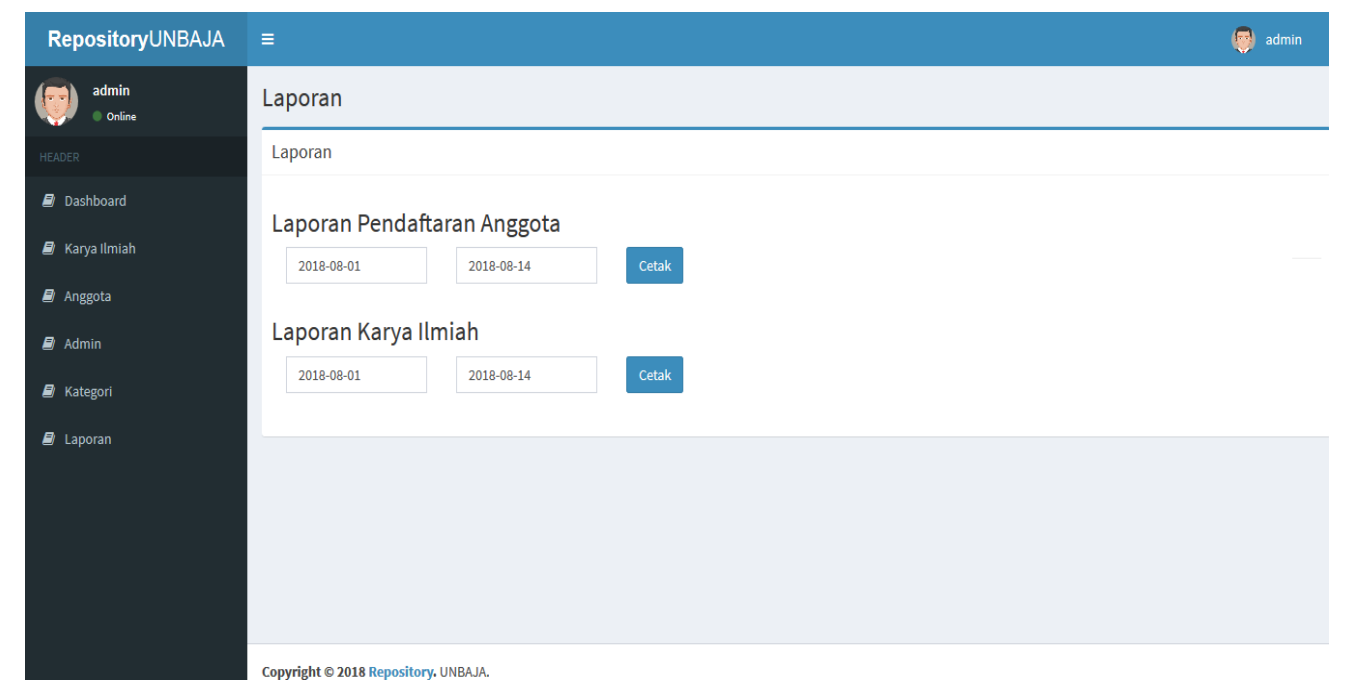

Gambar 17. Tampilan Form Input laporan

12) Fasilitas yang dimiliki oleh Anggota hanya terbatas pada pencarian karya ilmiah, mendownload karya ilmiah, mencetak kartu bebas anggota, bukti penyerahan laporan pkn, dan bukti penyerahan proposal. 
a. Tampilan Menu Anggota

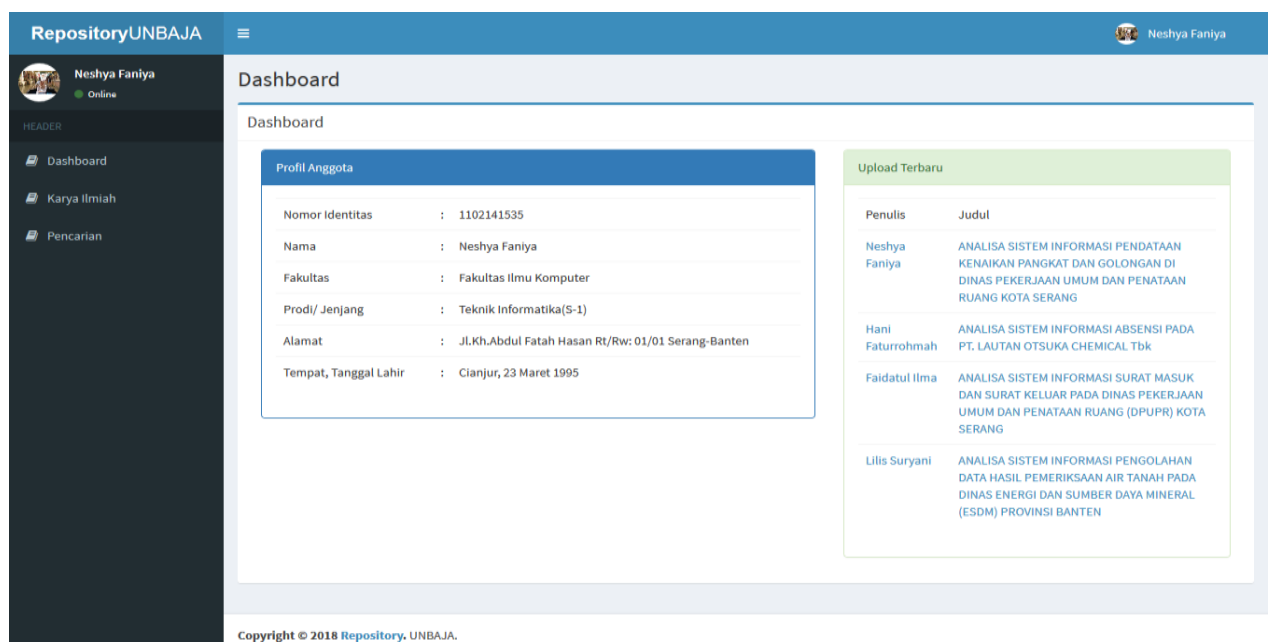

Gambar 18. Tampilan Menu Anggota

b. Tampilan Pencarian Karya Ilmiah

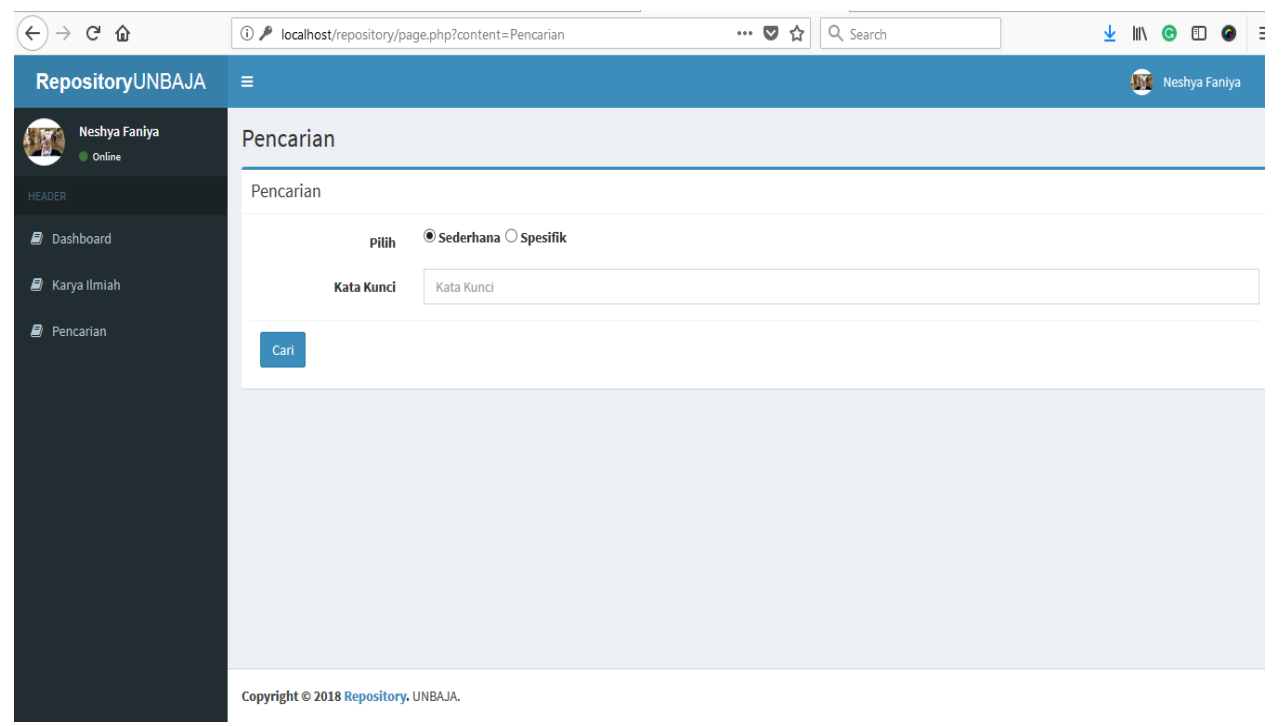

Gambar 19. Tampilan Pencarian Karya Ilmiah 
c. Detail Karya Ilmiah, form ini menampilkan data karya ilmiah secar rinci

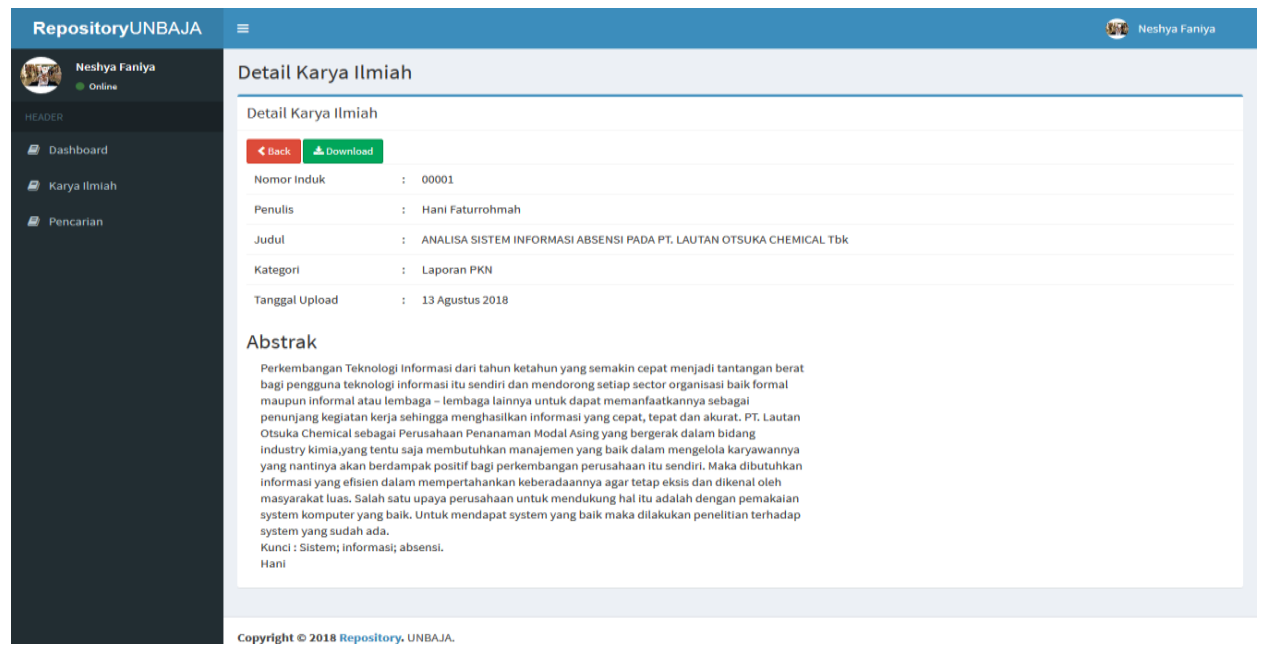

Gambar 20. Tampilan Detail Karya Ilmiah

\section{d. Surat Bebas Anggota}

Menampilkan Surat bebas anggota sebagai bukti telah menyerahkan skripsi dan tidak ada tunggkan denda buku telah menyerahkan laporan pkn atau proposal.

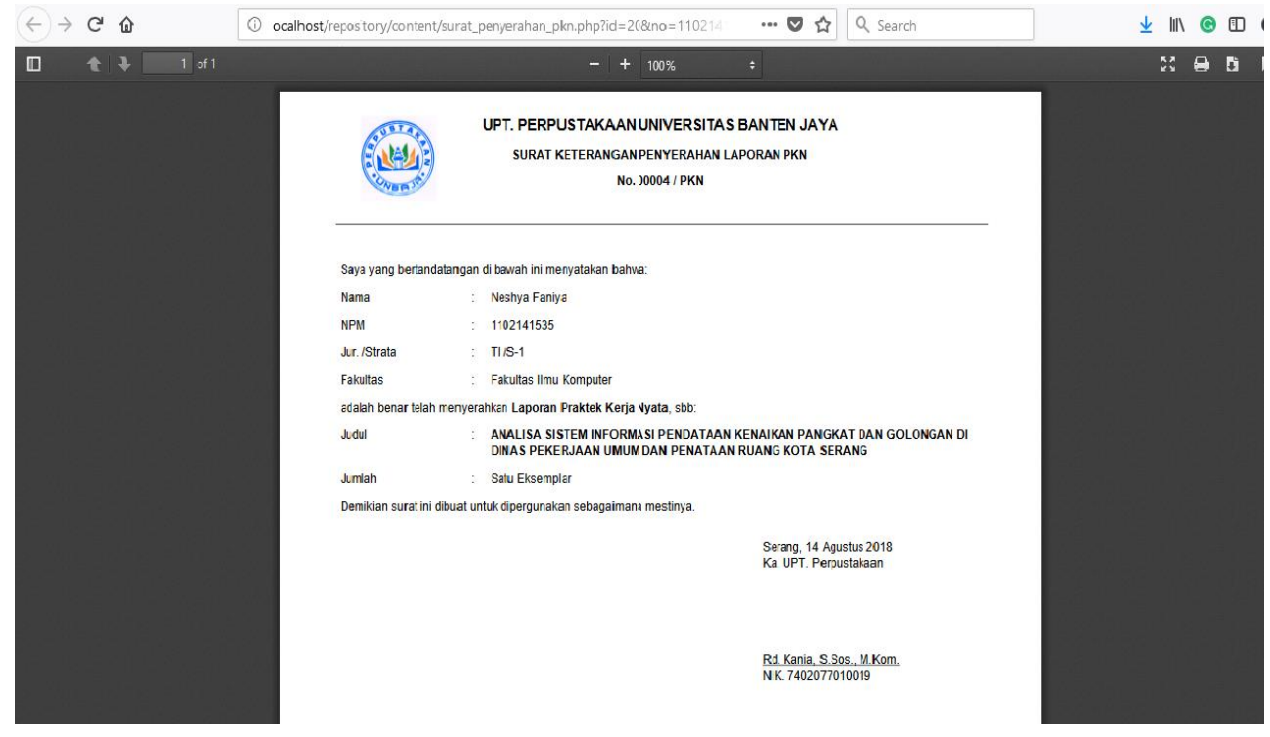

Gambar 21. Tampilan Surat Bebas Anggota 


\section{KESIMPULAN}

Berdasarkan pembahasan pada bab-bab sebelumnya tentang Aplikasi Repository pada perpustakaan Universitas Banten Jaya. Dapat diambil kesimpulan sebagai berikut:

1. Bahan pustaka yang telah didigitalkan dapat diakses pada komputer yang terdapat diperpustakaan. Dengan mendaftar sebagai anggota, Mahasiswa dapat menggunakan fasilitas yang ada pada sistem Repository tersebut. Dengan menggunakan Repository dapat mengurangi terjadinya kerusakan dan kehilangan karya ilmiah karena seringnya digunakan dan juga mempermudah para pengguna perpustakaan dalam mengakses dan menemukan bahan pustaka yang ada.

2. Aplikasi Repository dapat menghemat penggunaan ruangan, Rak dan fasilitas penunjang lain karena karya ilmiah dapat diakses dengan menggunakan perangkat yang tersedia pada perpustakaan maupun perangkat yang dibawa oleh para pengguna perpustakaan.

3. Dengan penerapan Aplikasi Repository dapat menghindari terjadinya keterlambatan dalam pengembalian kerya ilmiah. Karena proses pinjam digantikan dengan proses download sehingga semua anggota dapat mengakses karya ilmiah yang sama secara bersama.

\section{REFERENSI}

Alan Nur Aditya,,2011. Jago PHP \& MySQL. Bekasi : Dunia Komputer.

Adhie Tri Wahyudi, Bagus Ismail Adhi Wicaksana. 2015. Menuju Digital USB Repository: Integritas Digital Library Management System dan Aplikasi PDF Viewing dengan Java Script dan HTML 5. Jurnal Teknologi Informasi dan Ilmu Komputer. Vol.13,No.3.

Adi Wibowo, Resmi Lim. 2011. Repository Digital Berbasis OAI dan Repostory. Seminar Nasional Informatika.

Dhanta, 2009. Pengantar Ilmu Komputer. Surabaya : Indah.

Echols, Jhon M. dan Shadily, Hasan, 2006. Kamus Inggris Indonesia. Jakarta : PT Gramedia Pustaka Utama.

Hakim, Rahmad, 2010. Cara Mengolelola Blog. Jakarta : Alex Media Komputindo.

Hasan, 2012. UR Digital Repository Suatu Perjuangan Informasi. UPT Perpustakaan Universitas Riau. 
Kristianto, Andri, 2010. Kupas Tuntas PHP dan MySQL. Klaten : Cable Book.

Kustiyahningsih, Yeni. Anamisa, Devie, Rosa, 2010. Pemrograman Basis Data Berbasis Web Menggunakan PHP \& MySQL. Bangkalan : Graha Ilmu.

Muhammad Azhar Irwansyah. 2015. Sistem Repository Digital Beban Kerja Dosen. Jurnal Edukasi dan Penelitian Informatika (JEPIN). Vol.1,No.1.

Micheal Yoseph Ricky. 2012. Pengembangan Aplikasi Online Mobile Repository. Seminar Nasional Informatika.

Nur'aini, Hartoni, Jummy. 2017. Perancangan Aplikasi Mobile Repository Skripsi SMK IBBI Medan Berbasis Android. Jurnal Ilmiah Core IT.

Raharjo, 2011. Belajar Otodidak Membuat Database Menggunakan MySQL. Bandung : Informatika.

Sukanto, Rosa. Shalahuddin, 2013. Rekayasa Perangkat Lunak. Bandung : Informatika Bandung.

Yudi Hendra, 2009. VB 2008 Untuk Keperluan Pemrograman. Jakarta : PT Alex Media Komputindo.

Yuhefizar, 2008. 10 Jam Menguasai Internet : Teknologi dan Aplikasinya. Jakarta : PT alex Media Komputindo.

Yuhefizar, 2009. Cara Mudah Membngun Website Interaktif Menggunakan CMS Joomla, edisi revis. Jakarta : PT Alex Media Komputindo. 